\title{
Policy agenda-setting studies: an overview of Brazilian
}

\section{research}

\section{Ana Cláudia Niedhardt Capella 12}

1 Universidade Estadual Paulista "Júlio de Mesquita Filho" / Department of Public Administration, São Paulo / SP - Brazil

2 Universidade Federal de São Carlos / Graduate Programs in Political Science (PPGPOL) and in Management of Public

Organizations and Systems, São Carlos / SP - Brazil

This article aims to present a brief reflection on the studies in the field of the public policy agenda. To this end, the text presents the main theoretical and methodological developments on the subject found in the international literature, with an emphasis on three fundamental contributions: the studies developed by Cobb and Elder in the 1970s; John Kingdon's multiple streams model in the 1980s; and Baumgartner and Jones' propositions from the 1990s until the present. Next, we seek to understand how policy agenda-setting studies have been developed in Brazil. To do so, we conduct a mapping of the Brazilian academic production, considering theses, dissertations, and articles published in journals between 2000 and 2018. In conclusion, we note the growing expansion of agenda studies in Brazil, and we draw attention to some of the characteristics of these works, such as the preferred policy areas and the theoretical and methodological frameworks favored by researchers, among other aspects.

Keywords: policy agenda-setting; public policy; policy studies; policy formulation; public policy in Brazil.

\section{Estudos sobre formação da agenda de políticas públicas: um panorama das pesquisas no Brasil}

$\mathrm{O}$ artigo tem como objetivo apresentar uma breve reflexão sobre os estudos de agenda no campo das políticas públicas. Para isso, o texto apresenta os principais desenvolvimentos teóricos e metodológicos produzidos na literatura internacional sobre o tema, com ênfase em três contribuições fundamentais: os estudos desenvolvidos por Cobb and Elder nos anos 1970, o Modelo de Múltiplos Fluxos apresentado por John Kingdon nos anos 1980; e as proposições de Baumgartner e Jones nos anos 1990 até o presente. Na sequência, buscamos compreender como esses estudos têm sido desenvolvidos no contexto brasileiro. Para isso, realizamos um levantamento da produção acadêmica brasileira, considerando teses, dissertações e artigos publicados entre $200^{\circ}$ e 2018 . Como conclusão, observamos a expansão dos estudos sobre agenda e destacamos algumas de suas características, como as políticas setoriais mais estudadas pelos pesquisadores, os modelos teóricos mais populares, entre outros aspectos.

Palavras-chave: formulação de políticas públicas; agenda-setting; análise de políticas públicas; políticas públicas no Brasil.

\section{Estudios sobre formación de la agenda de políticas públicas: un panorama de la investigación en Brasil}

El artículo tiene como objetivo presentar una breve reflexión sobre los estudios de agenda en el campo de las políticas públicas. Para ello, el texto presenta los principales desarrollos teóricos y metodológicos producidos en la literatura internacional sobre el tema, con énfasis en tres contribuciones fundamentales: los estudios desarrollados por Cobb y Elder en la década de 1970, el modelo de flujos múltiples presentado por John Kingdon en la década de 1980; y las proposiciones de Baumgartner y Jones en la década de 1990 hasta el presente. Luego, buscamos comprender cómo se han desarrollado estos estudios en el contexto brasileño. Para ello, realizamos un relevamiento de la producción académica brasileña, considerando tesis, disertaciones y artículos publicados entre los años 2000 y 2018. Como conclusión, observamos la expansión de los estudios sobre agenda y destacamos algunas de sus características, como las políticas sectoriales más estudiadas por los investigadores, modelos teóricos más populares, entre otros aspectos.

Palabras clave: formulación de políticas públicas; agenda-setting; análisis de políticas públicas; políticas públicas en Brasil. 


\section{ACKNOWLEDGEMENTS}

This study was financed by the State of São Paulo Research Foundation - FAPESP (Regular line, grant number 2018/16289-3) and by The National Council for Scientific and Technological Development - CNPq (Grant number 424398/2018-4).

\section{INTRODUCTION}

Agenda setting is one of the most critical elements of the public policy process. The agenda is the range of issues considered important at any given moment by policymakers or people around them with influence (direct or indirect) on the decision-making process (Kingdon, 2003). The study of agenda setting can be understood as the process of transforming issues into government priorities in any policy area (health, education, economy, agriculture, and social welfare, among many others). Considering that attention is a scarce resource and that both individuals and organizations set priorities for action, agenda setting is a process that involves intense competition, in which problems and alternatives gain or lose attention from the government and society all the time (Capella, 2017). Writing on the subject, Zahariadis (2016, p. 3) defined the relevance of agenda studies by listing five main reasons: a) investigating the agenda helps us understand the social values at a given historical moment; b) it allows us to see potential gaps between priorities of the government and society; c) studying the agenda makes visible both winners and losers in the political game, revealing the priorities of different social groups; d) it broadens our understanding of policy options, decisions and choices; and, finally, e) studying the agenda allows us to see a broad set of actors and institutions, sometimes beyond those that are formally defined.

Although understanding agenda setting is fundamental for understanding the exercise of political power in a democratic context, agenda-setting studies are relatively recent in the international literature and, as we shall see, are still more recent in Brazil. Agenda studies have never been among the central concerns of the Brazilian public policy research community (or the public administration or even political science communities). In the most recent period, however, new issues and approaches related to the international literature of public policy have been circulating more intensely in the Brazilian academic community, leading to greater diversity in the research interests of scholars. In this context, research on the agenda in Brazil is developing, and we believe this is an expanding field of study.

To better understand this process, this study is organized into three sections in addition to this introduction. We begin by briefly presenting the main theoretical developments of the international literature. To this end, we highlight three fundamental contributions: the studies of Cobb and Elder in the 1970s; John Kingdon's breakthroughs in the 1980s; and Baumgartner's and Jones's propositions, which began to advance the studies in the early 1990s and are still under development. Later, we seek to identify the methodological pathways that underpin agenda research, trying to understand how scholars have effectively addressed the question of how to study the agenda. This theoretical and methodological balance, based on the international literature, stands as a reference for mapping the agenda research in Brazil. We considered the production of theses and dissertations, as well as articles in journals produced in Brazil on the subject. In conclusion, we note the growing expansion of agenda studies in Brazil, and we draw attention to some of the characteristics of these works, such as the 
preferred policy areas and the theoretical and methodological frameworks favoured by researchers, among other aspects. At the end of the paper, some general conclusions about the studies on policy agendas are presented.

\section{AGENDA SETTING: THEORETICAL DEVELOPMENTS}

One of the first studies that highlighted the agenda-setting process as a central element of the political process was conducted by Roger Cobb and Charles Elder (1972) ${ }^{1}$. In Participation in American Politics: The Dynamics of Agenda Building, the authors developed the notion of agenda setting (or agenda building, as they called it) as a part of the larger debate about democracy (Jones, 2016). An agenda, as they defined, is "a general set of political controversies that will be viewed at any point in time as falling within the range of legitimate concerns meriting the attention of the polity" (Cobb \& Elder, 1972, p. 14). In the book, they sought to understand the patterns of the relationship between public participation and elite decision-making. They distinguished between the systemic public agenda (the society or the informal agenda), the media agenda (the mass media agenda) and the institutional agenda (the state or the formal agenda). The systemic agenda "consists of all issues that are commonly perceived by members of the political community as meriting public attention and as involving matters within the legitimate jurisdiction of existing governmental authority" (Cobb \& Elder, 1972, p. 85). The authors stated that only a small portion of systemic issues are seriously considered by the government.

To explain how issues moved through these different agendas, Cobb, Ross, and Ross (1976) presented a model of agenda setting with three different patterns of initiation. In the first one, called the outside initiation model, issues arise in social groups, and they are expanded to other groups, reaching the public, or the systemic agenda, and then the institutional agenda. This model is compatible with liberal pluralist societies where claims are first articulated in generic terms to be later translated into more specific demands, establishing ties between different groups around common issues and thus reaching the systemic agenda. In this case, groups seek the attention of policymakers to move an issue to the institutional agenda. The second explanation about agenda building is the mobilization model, in which the movement occurs in the opposite direction: from the government to the public. In this model, decision-makers try to move an issue from the institutional to the systemic agenda, seeking support from the public to place it in the systemic agenda. The third model, inside initiation, explains situations in which issues originate within the government, but unlike the mobilization model, the public bureaucracy does not seek to expand the issues to the public. These issues arise within the bureaucracy - sometimes encouraged by influential groups with special access to decision-makers and there is no interest to bring them into the public debate. This can happen for technical or political reasons, but the initiation model excludes public participation. According to the authors, this model is compatible with authoritarian bureaucratic regimes.

\footnotetext{
${ }^{1}$ Despite the importance of Cobb and Elder's seminal studies in the field of public policy, the authors were not the first to deal with the agenda-setting process. Walter Lippmann postulated the relationship between the mass media and the public agenda in 1922; Paul Lazarsfeld and Robert Merton identified the function of the media in the salience given to issues in 1948; Maxwell McCombs and Donald Shaw investigated the public agenda-setting process for the hierarchy of issues in 1972. All these studies were developed in the field of political communication, with a low interface with agenda-setting studies in the field of public policy. For a broader analysis, which encompasses studies in the field of communication, see Dearing and Rogers (1996).
} 
In the following decades, as Rochefort (2016) shows, the concepts initially developed by Cobb and Elder were adopted by public policy textbooks. The explanation provided by the authors was successful in placing agenda setting at the centre of the democratic process, identifying distinct agenda-setting patterns and strategies. However, the agenda-setting process described by the authors is ultimately determined by the general nature of the political system (Howlett \& Ramesh, 2003). Although influential, the perspective proposed by the authors limits the explanations about the agenda-setting process in complex democratic systems.

Between the 1980s and 1990s, agenda-setting studies were reshaped with the emergence of theoretical approaches that no longer aimed at understanding the complex relationships between institutional and systemic agendas. These new models directed efforts to the investigation of issues moving through the institutional agenda. John Kingdon (2003) and Baumgartner and Jones (1993) advanced theoretically and empirically in the study of policy change.

John Kingdon's Agendas, Alternatives and Public Policies (published originally in 1984) advances theoretically by proposing a differentiation between the concepts of governmental agendas and decision agendas. The agenda is "the list of subjects or problems to which governmental officials, and people outside of government closely associated with those officials, are paying some serious attention at any given time" (Kingdon, 2003, p. 3). For the author, an issue is placed on the governmental agenda when it catches the attention and the interest of policymakers, as Cobb and Elder suggested. However, Kingdon expands the set of actors related to agenda-setting, considering not only decision-makers within the state but also individuals and groups related to them. In addition, given the complexity and the volume of questions facing policymakers, Kingdon reminds us that only a few issues are seriously considered within the governmental agenda at any given time. These issues correspond to the decision agenda: a subset of the governmental agenda where issues are ready for an active decision. In the highly competitive agenda-setting process, few issues move from the governmental agenda to the decision agenda. In his words, "we should also distinguish the governmental agenda, the list of subjects that are getting attention, and the decision agenda, or the list of subjects within the governmental agenda that are up for an active decision" (Kingdon, 2003, p. 4). Kingdon explains how agendas change from time to time, proposing an explanatory model organized around three streams: the problems stream, the policy stream, and the political stream. The multiple streams model proposed by the author seeks to analyse the pre-decisional stages of the policy process by explaining policy formulation through three streams connected by a public policy entrepreneur who plays an important role when windows of opportunity make changes possible.

Developed to analyse the United States, the multiple streams model has been successfully tested in diverse political and institutional contexts (Zahariadis, 2016). Jones et al. (2016, pp. 21-22) identified sixty-five countries analysed using the model, with Europe being the continent with the largest number of publications, followed by North America, Asia, Africa, and South America. Regarding the applicability of the model to different political systems, Cairney (2012) concludes that Kingdon's model is generalizable due to its basic assumption: the characterization of governments as organized anarchies and the presence of ambiguity, competition for attention, imperfect information, time constraints for decision-making, and non-rational comprehensive rationality. Similarly, Zahariadis (2014, p. 44) states, "It [the multiple streams model] constitutes a lens of the policy process that is 
useful in single-case or comparative applications across time, countries, issues, levels of governance, and policy domains".

Another valuable contribution to agenda-setting studies was presented by Frank Baumgartner and Bryan Jones. In Agendas and Instability in American Politics (published in 1993), the authors develop a theoretical model dedicated to explaining how agendas stay stable for long periods of time and how they are affected by processes of rapid and abrupt change. Building on concepts previously developed by Kingdon and other authors from political science and organization theory, Baumgartner and Jones advanced the explanation of agenda stability and change through their concept of policy monopolies: institutional settings capable of producing stability and thus inhibiting change over long periods of time (negative feedback). On the other hand, when these monopolies break down, making room for new understandings and actors, one must expect rapid and abrupt changes in the agenda (positive feedback) (Baumgartner \& Jones, 1993; True, Jones, \& Baumgartner, 1999).

In subsequent work, the authors further investigated stability and change in the agenda through a more detailed analysis of positive and negative feedback processes and showed that these processes occur not only within previously investigated monopolies but also throughout the United States political system (Baumgartner \& Jones, 2002). While change was first understood as the result of a complex combination of ideas and institutions within policy monopolies (Baumgartner \& Jones, 1993), in The Politics of Attention (Jones \& Baumgartner, 2005), the authors advance in the investigation of the relationship between punctuations and information processing or the act of "collecting, assembling, interpreting, and prioritizing signals from the environment" (Jones \& Baumgartner, 2005, p. 7). Information is characterized by uncertainty and ambiguity. Policymakers capture signals (detectable change) by selecting information, prioritizing some aspects of it and ignoring others. The key element that explains punctuations in the United States political system is the way policymakers engage in selective attention, focusing attention on some issues rather than others. Thus, the authors advanced from a "punctuated equilibrium model", which proposed explanations for the changes in policy monopolies linked to case studies (Baumgartner \& Jones, 1993), to a general punctuation thesis (Jones \& Baumgartner, 2005), a more general approach that highlights the role of information processing in the political system as a whole. More recently, another dimension of this problem was developed by the authors, involving the relationship between information processing and the problem definition process (Baumgartner \& Jones, 2015). Zahariadis (2016, p. 14) notes that Baumgartner and Jones's agenda-setting model contributes in two significant ways to the literature. First, their model employs sophisticated techniques of quantitative analysis, an element absent from earlier agenda-setting models. Second, the theorizations developed by the authors allow comparative investigations, generating successful explanations in different national contexts.

Punctuated equilibrium theory and its subsequent developments also helped shape contemporary studies that seek to understand broader processes of policy change not only in different political systems but also comparatively in many countries, magnifying the limits and possibilities of agenda-setting theories (Baumgartner, Green-Pedersen, \& Jones, 2006; Baumgartner, Jones, \& Mortensen, 2014; Baumgartner, Jones, \& Wilkerson, 2011). These studies proved the feasibility of 
explanations of stability and change in public policy based on the formulations of Baumgartner and Jones in different political systems. Despite institutional differences, there are dynamics of policy change with the characteristic punctuation in several countries (Baumgartner et al., 2006).

This new moment of agenda-setting studies in the field of public policy, involving comparative analysis of different policy agendas, is still under development and faces a growing number of challenges (Baumgartner, Breuning, \& Grossman, 2019). Despite these challenges, research has shown that the theoretical and methodological framework developed on the basis of Baumgartner and Jones' formulations on agenda-setting has contributed significantly to the study of comparative public policy.

\section{HOW CAN AGENDA SETTING BE STUDIED? METHODOLOGICAL ISSUES}

From a methodological point of view, the approaches to policy agenda setting briefly summarized in the previous section present different strategies, with a strong emphasis on case studies as a research method. The research initiated by Cobb and Elder laid the conceptual foundation for agenda studies (Jones, 2016). In Participation in American Politics (Cobb \& Elder, 1972), the authors employed several examples of policies to exemplify theoretical aspects under discussion. According to Rochefort (2016, p. 35), "typically these were mentions made in passing, sometimes in only few sentences to drive home the author's larger points about their explanatory model". One chapter of the book is dedicated to case studies: a coal mining strike in West Virginia, a grape picker strike in southern California, debates about the anti-ballistic missile system and the federal income tax. Considering these selected cases, the authors sought to understand how issue expansion was related to conflict within the context of an agenda-setting perspective. In later works, such as The Politics of Problem Definition (edited by Rochefort and Cobb in 1994) and Cultural Strategies of Agenda Denial (edited by Cobb and Ross in 1997), the books were composed of chapters written by several authors dedicated to different policy issues (air transportation policy, national antidrug policy, tax policy and agriculture, and AIDS, among others, in the first case, and security and exchange commission, food and drug administration, and public health, in the second case).

Exploring agenda studies produced until the 1990s, Dearing and Rogers (1996) conclude that researchers adopt a great diversity of approaches. They also find that scholars do not share standardized ways of measuring the policy agenda. Considering the tradition of other agenda studies (such as the media agenda or the public agenda, studies commonly conducted in the field of communication), the authors show that policy agenda studies present the greatest methodological variation: "The policy agenda for an issue or issues is measured by such policy actions as the introduction of laws about an issue, by budget appropriations, and by the amount of time given to debate an issue in the U.S. Congress. Measures of the policy agenda vary from study to study much more than do measures of the media agenda or the public agenda, which are fairly standard" (Dearing \& Rogers, 1996, p. 18).

John Kingdon's multiple streams model (2003) was developed using different methodological resources, including interviews with senior civil servants and those close to them, case studies 
on public policy initiation, and examination of public documents (records of public hearings, presidential speeches, party platforms, press reports, and public opinion polls). The two largest sources of data, according to the author, consisted of interviews and case studies (Kingdon, 2003, p. 231). To analyse the data collected through the interviews, the author employed qualitative and quantitative techniques. To measure the status of an issue on the agenda, codes were created (approximately 200 items), and each interview was coded by two researchers independently. Regarding case studies - the second largest source of data used in the investigation - government documents, reports, academic articles and other written sources were collected, which served to better understand the process. Kingdon considered 23 cases as the unit of analysis, which were coded according to the same parameters as the interviews by two independent investigators. Agenda indicators other than interviews and case studies, such as public hearings, presidential speeches, media coverage, public opinion polls, and party platforms, were also analysed. The author concluded that these sources were not as useful as the interviews (Kingdon, 2003). Exploring case studies that applied Kingdon's model, Cairney and Jones (2015) point out that most studies follow the same path, relying on interviews, in addition to document analysis, for conducting the investigations.

Unlike the methodological strategy adopted by Kingdon, Baumgartner and Jones relied mainly on the content analysis of written documents. In part, this choice is due to the period under consideration: Kingdon investigated two policies (transportation and health) for four consecutive years; Baumgartner and Jones initially focused on multiple policies (pesticides, smoking, alcohol, drugs, urban issues, nuclear power, and child abuse) for a few decades, reaching periods of approximately one hundred years (Baumgartner \& Jones, 1993).

The authors proposed a research design capable of combining two types of studies: longitudinal studies, investigating a single issue in its various stages of development over time, and cross-sectional studies, analysing several issues at a single moment in time. Longitudinal studies are suitable for analysing issues entering and leaving the agendas, but they are hardly generalizable or comparable. Cross-sectional studies explain why some issues reach a high level of attention on the agenda, while others remain out of consideration. For agenda-setting studies, both perspectives are important and complementary, although researchers have often relied on case studies, not making systematic use of longitudinal data, as is the case with the analysis undertaken by Kingdon (Baumgartner \& Jones, 1993, p. 47).

To develop this new approach, the authors initially considered congressional hearings and media coverage to trace the attention to nuclear power, pesticides, drug abuse, and other issues. They used public indices to obtain the data and conducted the analysis using content analysis techniques, which allowed the categorization of large portions of textual material. In each of the datasets, documents were indexed using keywords, allowing the authors to collect and systematize information about hundreds of audiences and newspaper editions over a long period of time (Baumgartner, Jones, \& MacLeod, 1998, p. 2).

This initial research effort, which resulted in the book published in 1993, laid the foundation for a more ambitious project - the Policy Agendas Project. For this new stage of the research, data 
sources were expanded to seven major sets (Congressional Hearings; Congressional Quarterly; public laws; Presidential Executive Orders; Gallup Most Important Problems Series; New York Times index; U.S. Congressional Budget Authority). Each of the datasets was analysed according to the same codebook structure to keep track of changes in the agenda over time. This code structure was organized around the main aspects of public policies, such as health, agriculture, education, energy, defence, and macroeconomics. For each of the codes (initially 21 items), several sub codes were developed, allowing analyses to be performed at higher or lower levels of aggregation (Baumgartner et al., 1998). Thus, the Policy Agendas Project can be summarized into a large set of comparable data, spanning a few decades, that allows the observation of an issue's status over time, as well as periods of rapid change in various policy areas (Baumgartner, Jones, \& Wilkerson, 2002, p. 45).

These data allowed the emergence of new theoretical questions, resulting in the book The Politics of Attention (Jones \& Baumgartner, 2005). At this time, the explanations of the punctuated equilibrium model matured, and the authors moved towards the general punctuation thesis (Jones \& Baumgartner, 2005) $)^{2}$. While the authors developed the Policy Agendas Project datasets and refined the theoretical explanations, scholars began to expand the Policy Agendas methodology outside of the United States. As a result, the Comparative Agendas Project - a research network that brings together scholars from different countries interested in studying agendas in different political systems by sharing the same methodological path originally defined by Baumgartner and Jones - was structured, encouraging comparative studies of public policy (Baumgartner et al., 2006) $)^{3}$.

This new moment in the trajectory of agenda-setting studies involving comparative research is still under development and faces several theoretical and methodological challenges. Despite these challenges, some advances can already be seen, largely as a result of the expansion of the project to new countries, research communities and questions (Baumgartner et al., 2019).

\section{STUDYING POLICY AGENDA-SETTING IN BRAZIL}

Studies on agenda-setting in Brazil are under development, partly as a reflection of the trajectory of public policy research in the country, a relatively recent field of knowledge, and still under construction. Historically, the social sciences in Brazil have developed with a focus on the state, with a strong historical and sociological perspective, associating policy analysis with

\footnotetext{
${ }^{2}$ The authors also name this process "disruptive dynamics" in the second edition of Agendas and Instability in American Politics, published in 2009 .

${ }^{3}$ The Comparative Agendas Project (CAP) is currently composed of 25 projects: 22 are nationals projects (Australia, Belgium, Brazil, Canada, Croatia, Denmark, France, Germany, Hungary, Israel, Italy, Netherlands, Spain, New Zealand, Portugal, Switzerland, United Kingdom, China, Russia, South Korea, the United Kingdom and the United States) 2 U.S. states (Florida and Pennsylvania) and 1 supranational project (European Union). Brazil joined the CAP at the end of 2014, and the Brazilian Policy Agendas Project brings together researchers, $\mathrm{PhDs}$, and $\mathrm{PhD}$, master and undergraduate students focused on the investigation of agenda formation in Brazil. This research effort, based at Sao Paulo State University (UNESP-Araraquara), had academic support from the CAP community and financial support from the CNPQ and FAPESP. Data and other materials produced by CAP scholars can be found here: https://www.comparativeagendas.net/
} 
government entities (Arretche, 2003; Melo, 1999). Thus, until the 1980s, the social sciences were characterized by a state-centred research agenda and its connections with the political system and social foundations, strongly influenced by Marxism and structuralism (Hochman, Arretche, \& Marques, 2007). On the other hand, the field of public administration was designed to provide training for public servants, initially influenced by law and later by "administrative science" (Keinert, 2000). The Brazilian public administration produced studies in the field of public policy in the late 1960s, but the issue quickly lost importance in the research agenda, which was more focused on efficiency and administrative techniques (Farah, 2013). It is in the most recent period that new themes and approaches related to the international literature in the field of public policy have been circulating more intensely in the Brazilian community, in both the social sciences and the public administration. In the social sciences, a new research agenda has been established since the 1980s, and it seeks to examine the institutional characteristics of the Brazilian state and specific policy areas (Arretche, 2003). In addition, Brazil's own political agenda, involving the process of re-democratization in the 1980s, boosted researchers' interest in examining specific policy areas, a feature that was accentuated in the 1990s (Hochman et al., 2007; Souza, 2007). In the early 2000s, the public administration area approached public policy analysis as a result of an unprecedented expansion of undergraduate and graduate education in public policy and related areas (such as public management, social management and public policy management) (Farah, 2016).

Thus, if public policy studies are recent in the country, it is worth asking the following questions: how has knowledge of the policy agenda process developed in Brazilian academia? Are agenda studies following the expansion of the public policy field observed in the recent period? How has knowledge about the theme developed, both quantitatively and qualitatively? How is the international literature on agenda setting embraced by Brazilian researchers?

Specifically, observing the research on agenda-setting, we can highlight some findings from research conducted on the doctoral theses and master's dissertations produced in Brazil ${ }^{4}$. Focusing on this kind of academic work allows us to understand how Brazilian researchers are adopting the recent literature on agendas, how concepts are employed, and how agenda studies are conducted by scholars. In this mapping of postgraduate academic production, we specifically looked for theses and dissertations on agenda-setting that mentioned the models of John Kingdon or Baumgartner and Jones ${ }^{5}$. As a result, we found 161 studies produced between 2000 and 2018: 49 doctoral theses and 112 master's dissertations (academic and professional). It is interesting to note a significant increase in these studies as illustrated in the chart below:

\footnotetext{
${ }^{4}$ The research covered theses and dissertations produced in Brazilian universities and research institutions, available in two databases: Catálogo de Teses e Dissertações da CAPES (Retrieved from http://catalogodeteses.capes.gov.br/catalogo-teses) and Biblioteca Digital Brasileira de Teses e Dissertações (Retrieved from http://bdtd.ibict.br/vufind/).

${ }^{5}$ We employed the following keywords: "múltiplos fluxos"; "multiple streams"; "Kingdon and agenda", "fluxos and Kingdon"; "equilíbrio pontuado"; "equilíbrio interrompido"; "equilibrium and Baumgarter”; "punctuated and Baumgartner".
} 
Distribution of publications by year

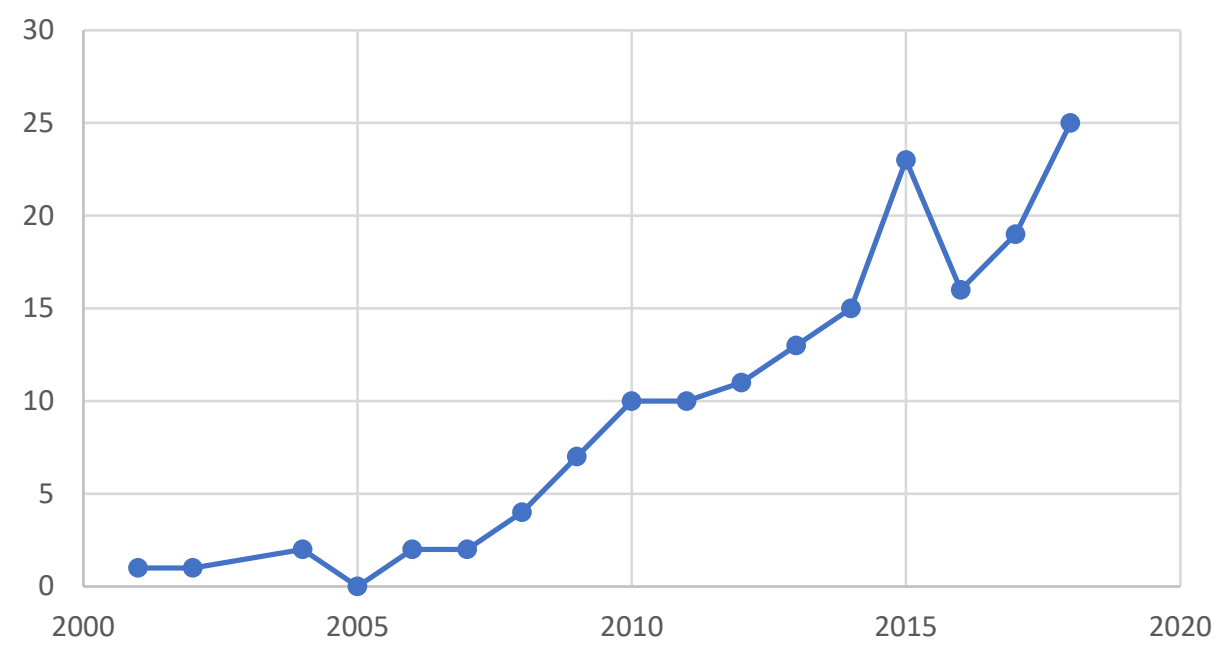

Source: Elaborated by the authors.

The studies were conducted in 39 Brazilian educational institutions and research centres, and it is possible to observe that ten institutions produced $62.7 \%$ of the national production on the issue. In this group, the institution that concentrated the largest proportion of studies was the University of Brasilia (UnB, 13\%), followed by Sao Paulo School of Business Administration (EASP-FGV, 11,2\%), Federal University of Rio Grande do Sul (UFRGS, 8,1\%), University of Sao Paulo (USP, 6,2\%), Federal University of Bahia (UFBA, 5,6\%), Federal University of Sao Carlos (UFSCar, 5\%), Federal University of $\mathrm{ABC}$ (UFABC, 3,7\%), Federal University of Parana (UFPR, 3,7\%), Oswaldo Cruz Foundation (FIOCRUZ, 3,1\%), and Federal University of Rio Grande do Norte (UFRN, 3,1\%). Only one of these ten institutions is private, and the others are public organizations.

Considering the set of 39 identified institutions, most of the work was produced by state and federal universities and research institutes. In these 39 institutions, we have identified 81 distinct postgraduate programmes in different areas of knowledge. Administration programmes (16.8\%) and public administration programmes $(16.1 \%)$ produced many theses and dissertations on agenda setting, as well as did programmes in the social sciences and sociology (16.8\%) and political science (15.5\%). Public health programmes also stand out in agenda studies (9.3\%), as well as programmes related to urban and regional planning (7.5\%). Specific public policy programmes have produced agenda studies in the most recent period (7.5\%). Studies were also found in education programmes (3.7\%) and social work (1.9\%).

Regarding the policy areas chosen by the researchers, we can highlight that almost half of the studies are concentrated in four policy areas: health (18.6\%), education (13.7\%), urban/regional development (11.8\%), and management (8.1\%). Issues such as civil rights $(7.5 \%)$, social policies $(6.8 \%)$, public safety (5\%), environment (3.7\%), labour (3.1\%), and infrastructure (3.1\%) appear next, as the 
most studied areas. Communication, science and technology, culture, and defence are also areas of interest ( $2.5 \%$ each), followed by energy, housing, transport, and tourism ( $1.9 \%$ each). Finally, sports and social security appear as areas of research interest $(1.2 \%$, which is the same percentage of studies that did not elect a specific area).

In addition to reviewing the quantitative data, which help us obtain an overview of the agenda-setting literature in Brazilian postgraduate studies, it is interesting to note how these studies were conducted from the perspective of theoretical and methodological choices ${ }^{6}$. Most of the identified studies consist of exploratory research using qualitative methods to promote knowledge about sectoral policy. Case studies and bibliographic research are often used. Most studies are based only on John Kingdon's model, with no mention of other policy agenda-setting frameworks. In this case, many of the researchers chose to apply concepts formulated by Kingdon, and a smaller portion sought to use the model as an analytical tool. This means that the researchers did not use multiple streams as "theoretical lenses"; instead, they employed some basic concepts of the model (pursuing an explanation of one or more streams, drawing attention to a policy entrepreneur, for example), without explaining the dynamics of agenda change originated by the coupling of problems, politics, policy, and participants. Considering the works found, $46.8 \%$ fit in this category. These are studies that consist of the analysis of a policy area, basically presenting its history and systematizing the literature about it and, at some point, inserting concepts formulated by Kingdon in a very punctual way. This type of study usually seeks the help of other theoretical approaches, notably the new historical institutionalism, the literature on federalism, and specific studies on the policy areas under analysis. Other studies build on the multiple streams model and effectively use it as an analytical model to explain major agenda changes in a policy area. Studies of this type (22.4\%) also seek other theoretical references (mainly related to the policy area under investigation). The third largest group of studies mobilize Kingdon's and Baumgartner and Jones's concepts in a combined manner (14.1\%). These works include the earliest texts by Baumgartner and Jones (especially "Agendas and Instability in American Politics"); that is, there is very little use of the authors' most recent articles and books. Moreover, few studies use only the latter authors' concepts without relying on Kingdon's concepts (only $5.8 \%$ of the works make use of the punctuated equilibrium concepts without mentioning Kingdon). We also found studies based on the model that were not intended to investigate processes of agenda change but aimed to observe issues related to changes in the public budget (these studies are not considered above).

It is also observed that many researchers do not aim to investigate agenda setting or policy formulation processes: they are willing to study policy actors, ideas and institutions, and for this purpose, they employ the concepts of multiple streams and punctuated equilibrium. In this case, combinations of the concepts of the agenda literature with other authors associated with post-positivism and the argumentative turn are frequent. Some studies also use concepts of the advocacy coalition framework for this purpose (4.5\% of all papers combine concepts from the multiple streams, punctuated equilibrium and advocacy coalition frameworks). Finally, looking at postgraduate production, we understand that some studies take another direction and provide an

\footnotetext{
${ }^{6}$ This survey was conducted based on the reading of abstracts found in theses or dissertations; in the case of studies in which the abstract did not clarify how the models were used by the authors, the summary and bibliographic references were analysed.
} 
analysis of policy considering the stages of the policy process. In this context, to discuss the agenda and formulation stage, they rely on Kingdon's concepts (6.4\%). Studies with these characteristics were found in programmes from more specialized areas (such as defence).

We also extend the analysis to publications in Brazilian academic journals ${ }^{7}$. The conversion rate of theses and dissertations into articles published in journals is quite low, which raises several questions about postgraduate studies and their perspectives. We found 23 articles published from 2011 to 2018 (01 in 2011; 3 in 2012; 2 in 2013; 3 in 2014; 2 in 2015; 4 in 2016; 2 in 2017 and 6 in 2018). Of these articles, 10 applied concepts from the multiple streams model; 10 sought to effectively apply Kingdon's model; 1 used only the concepts of punctuated equilibrium (focusing not on studying the agenda but on analysing the budget) and 2 performed literature reviews. The journals with the most publications belong to the areas of health ( 8 articles) and administration/public administration ( 8 articles). The other articles were found in sociology journals (1), political science (1), tourism (1), education (1), communication (1), physical education (1), and multidisciplinary approaches (1).

In view of these findings, we can conclude that research on policy agendas has been expanding at the postgraduate level and that theoretical models on agendas, especially the multiple streams model, have had significant insertion in these works. Agenda studies in Brazil consist of qualitative case studies devoted to sector-specific policy research, many of which rely on theoretical concepts of agenda studies, combining them with other concepts and with the historical and institutional context of the policy under analysis. Few of these studies, however, are transformed into articles, which still hinders the accumulation of knowledge and advances in this field of study in Brazil.

\section{CONCLUSION}

The policy agenda-setting literature has evolved since the 1970s, both theoretically and methodologically. We can say that this literature is currently based on solid concepts and that it stimulates research in different parts of the world. From a methodological point of view, there is wide diversity, reflecting the multiple choices of researchers in terms of the data sources, indicators and characteristics of the policy areas they choose to study. An important trend in the international literature is related to the articulation of a network of researchers dedicated to the study of agendas through shared theoretical and methodological assumptions. The Comparative Agendas Project is an example of a successful initiative in this regard. The project enables different researchers, with different backgrounds and interests, to be brought together around a shared goal: looking at agenda changes over time in different countries. In this sense, we can think of the project as a new field of study, with a growing community of researchers, new questions and goals (Baumgartner et al., 2019).

Agenda-setting studies in Brazil have been expanding in recent years, and there is still a long way to go. The public policy research conducted in Brazil has increasingly mobilized the international literature on agenda-setting, and the most important references in the field are known by Brazilian researchers. This fact reaffirms the perception of several authors who defend the validity of these

\footnotetext{
${ }^{7}$ The articles published in Brazil were collected from two research databases: SCIELO - Scientific Electronic Library Online (Retrieved from http://www.scielo.br) and OASIS - Brazilian Portal of Open Access Scientific Publications (Retrieved from http://oasisbr.ibict.br/). The keywords adopted were the same ones used in the mapping of theses and dissertations.
} 
RAP | Policy agenda-setting studies: an overview of Brazilian research

theoretical models for explaining agenda changes in different political systems. It is noteworthy that much of this research has not been published in journals, and the causes of this discrepancy need to be better understood. There seems to be a preference of Brazilian researchers for the multiple streams model, whether it is understood as a model for investigating agenda changes or as a set of concepts useful for understanding broader processes of change in public policy. On the other hand, there is still little use of studies originating from the punctuated equilibrium model, perhaps due to the model's greater methodological complexity, which requires a broader data set. In this regard, we hope that the activities carried out by Brazilian researchers in the Comparative Agendas Project will strengthen and stimulate new research on agenda setting in Brazil. 


\section{REFERENCES}

Arretche, M. T. S. (2003). Dossiê agenda de pesquisas em políticas públicas. Revista Brasileira de Ciências Sociais, 18(51), 7-10.

Baumgartner, F. R., Breunig, C. \& Grossman, E. (2019). The Comparative Agendas Project: Intellectual roots and current developments. In F. R. Baumgartner, C. Breunig, \& E. Grossman. (Eds.), Comparative Policy Agendas: Theory, Tools, Data. Oxford, UK: Oxford University Press.

Baumgartner, F. R., Breunig, C., \& Grossman, E. (Eds.). (2019). Comparative Policy Agendas: Theory, Tools, Data. Oxford, UK: Oxford University Press.

Baumgartner, F. R., \& Jones, B. D. (1993). Agendas and Instability in American Politics. Chicago, IL: University of Chicago Press.

Baumgartner, F. R., \& Jones, B. D. (2015). The politics of information: problem definition and the course of public policy in America. Chicago, IL: University of Chicago Press.

Baumgartner, F. R., Green-Pedersen, C., \& Jones, B. D. (2006). Comparative studies of policy agendas. Journal of European Public Policy, 13(7), 959-974.

Baumgartner, F. R., \& Jones, B. D. (Eds.). (2002). Policy dynamics. Chicago, IL: University of Chicago Press.

Baumgartner, F. R., Jones, B. D., \& Macleod, M. C. (1998, Spring). Lessons From the Trenches: Ensuring quality, reliability, and usability in the creation of a new data source. The Political Methodologist, 8(2), 1-10.

Baumgartner, F. R., Jones, B. D., \& Mortensen, P. B. (2014). Punctuated Equilibrium Theory: explaining stability and change in public policymaking. In P. A. Sabatier, \& C. Weible. (Eds.), Theories of the Policy Process (3. ed). Boulder, CO: Westview Press.

Baumgartner, F. R., Jones, B. D., \& Wilkerson, J. D. (2002). Studying Policy Dynamics. In F. R. Baumgartner, \& B. D. Jones. (Eds.), Policy Dynamics. Chicago, IL: University of Chicago Press, 2002.

Baumgartner, F. R., Jones, B. D., \& Wilkerson, J. D. (2011). Comparative Studies of Policy Dynamics. Comparative Political Studies, 44(8), 947-972.

Cairney, P. (2012). Understanding public policy: theories and issues. London, UK: Palgrave-Macmillan.

Cairney, P., \& Jones, M. D. (2015, June). Kingdon's Multiple Streams Approach: What is the empirical impact of this universal theory? Policy Studies Journal, 44(1), 37-58. Retrieved from http:// onlinelibrary.wiley.com/doi/10.1111/psj.12111/ abstract

Capella, A. C. N. (2017). Formulação de Políticas Públicas. (Coleção Governo e Políticas Públicas). Brasília, DF: ENAP.

Cobb, R. W., \& Elder, C. D. (1971). The Politics of Agenda-Building: An Alternative Perspective for Modern Democratic Theory. Journal of Politics, 33(4), 892-915.

Cobb, R. W., \& Elder, C. D. (1972). Participation in American Politics: The dynamics of agenda building. Boston, MA: Allyn and Bancon.

Cobb, R. W., \& Ross, M. H. (Eds.). (1997). Cultural strategies of agenda denial. Lawrence, KS: University Press of Kansas.

Cobb, R. W., Ross, J. K., \& Ross, M. H. (1976). Agenda Building as a comparative political process. American Political Science Review, 70(1), 126-138.

Dearing, J. W., Rogers, E. M. (1996). Agenda-Setting. Thousand Oaks, CA: SAGE.

Farah, M. F. S. (2013). A contribuição da Administração Pública para a constituição do campo de estudos de políticas públicas. In E. Marques, \& C. A. P. Faria. (Eds), A Política Pública como Campo Multidisciplinar. São Paulo, SP: Unesp.

Farah, M. F. S. (2016, Nov./Dec.). Análise de políticas públicas no Brasil: de uma prática não nomeada à institucionalização do "campo de públicas". Revista de Administração Pública, 50(6), 959-979.

Hochman, G., Arretche, M. T. S., \& Marques, E. (2007). Políticas Públicas no Brasil. Rio de Janeiro, RJ: Fiocruz.

Howlett, M., \& Ramesh, M. (2003). Studying public policy: policy cycles and subsystems. Oxford, UK: Oxford University Press.

Jones, B. D. (2016). A radical idea tamed: the work of Roger Cobb and Charles Elder. In N. Zahariadis. (Org.), Handbook of public policy agenda setting. Cheltenham, Northapton: Edward Elgar. 
Jones, B. D., \& Baumgartner, F. R. (2005). The politics of attention: how government priorizes problems. Chicago, IL: University of Chicago Press.

Jones, M. D., Peterson, H. L., Pierce, J. J., Herweg, N., Bernal, A., Raney, H. L., ... Zahariadis, N. (2016). A river runs through it: a multiple streams metareview. Policy Studies Journal, 44(1), 13-36.

Keinert, T. M. M. (2000). Administração Pública no Brasil: Crises e mudanças de paradigmas. São Paulo, SP: Fapesp.

Kingdon, J. (2003). Agendas, Alternatives, and Public Policies (3a. Ed.) New York, NY: Harper Collins.

Melo, M. A. (1999). Estado, governo e políticas públicas. In S. Miceli. (Org.), O Que ler na ciência social brasileira. São Paulo, SP: Ed. Sumaré.

Rochefort, D. A. (2016). Agenda setting, problem definition, and their contributions to a political policy analysis. In N. Zahariadis. (Org.), Handbook of public policy agenda setting. Cheltenham, Northapton: Edward Elgar.

Rochefort, D. A., \& Cobb, R. W. (Eds.). (1994). The Politics of Problem Definition: Shaping the Policy
Agenda. Lawrence, KS: University of Kansas Press.

Souza, C. (2007). Estado da arte da pesquisa em políticas públicas". In G. Hochman, M. Arretche, \& E. Marques. (Orgs.), Políticas Públicas no Brasil. Rio de Janeiro, RJ: Fiocruz.

True, J. L. Jones, B. D., \& Baumgartner, F. R. (1999). Punctuated-Equilibrium Theory: explaining stability and change in american policymaking. In P. A. Sabatier. (Ed.), Theories of the Policy Process. Oxford, UK: Westview Press.

Zahariadis, N. (2014). Ambiguity and multiple streams. In P. A. Sabatier, C. M. Weible. (Ed.), Theories of the Policy Process (3. ed.). Boulder, CO: Westview Press.

Zahariadis, N. (2016). Setting the agenda on agendasetting: definitions, concepts, and controversies. In N. Zahariadis. (Org.), Handbook of public policy agenda setting. Cheltenham, Northapton: Edward Elgar.

Zahariadis, N. (Org.). (2016). Handbook of public policy agenda setting. Cheltenham, Northapton: Edward Elgar.

\section{Ana Cláudia Niedhardt Capella}

https://orcid.org/0000-0002-1423-898X

Ph.D. in Social Sciences, Federal University of São Carlos (UFSCar); Assistant professor at the Department of Public Administration at Sao Paulo State University (UNESP); Professor of the Graduate Programs in Political Science (PPGPOL) and in Management of Public Organizations and Systems (PPGGOSP) at the Federal University of São Carlos (UFSCar). E-mail: ana.capella@unesp.br 